\title{
Food shortages and hunger as a global problem
}

\author{
Nadezhda Anatolyevna GONCHAROVA ${ }^{1 *}$ (D), Natalia Vadimovna MERZLYAKOVA ${ }^{1}$ (D)
}

\begin{abstract}
The gist of this article boils down to the study of the food problem as a global problem of the modern economy. The food problem cannot be tackled in isolation from other complex global challenges facing humankind. At present, there is no state in the world in which the production, distribution, and foreign trade in foodstuffs would not be a serious concern of the central authorities. And in this respect, the problem under consideration also acts as a planetary one, despite the fact that some countries are faced with a chronic lack of food, in others, the current goal has become a qualitative improvement in the diet in order to bring it closer to scientifically grounded norms, and some are even forced "to fight" with the surplus of manufactured products and diseases of the population caused by their excessive consumption. Only those countries that are actively reforming and modernizing their agriculture have achieved success in the fight against hunger and poverty. A methodical approach to the food problem is being developed; it is possible to cope with the problem of hunger. Depending on the value of the hunger index, three basic strategies are proposed to combat the food problem. The final positioning concept is formulated in the paper.
\end{abstract}

Keywords: food problem; hunger; social distress; food security; consumption.

Practical Application: The basic strategies for tackling the food problem proposed by the authors can be used to combat hunger and poverty in various countries.

\section{Introduction}

The scale of hunger has been repeatedly reviewed and analyzed in the scientific Russian and foreign literature (Baer et al., 2015; Balakina, 2015; DeBacker et al., 2015; Goncharova et al., 2018, 2019; Izakova \& Kapustina, 2018; Kapoguzov, 2019; Karkh \& Morozova, 2018; Kemsley et al., 2019; Konnikov et al., 2020; Merzlyakova \& Goncharova, 2020; Pisani et al., 2017; Ssennoga et al., 2019; Swaffield et al., 2018; Yousefi et al., 2020; Zavorohina et al., 2019; Zavorokhina et al., 2019).

Mass famine is defined as "a social disaster caused by prolonged food shortages and leading to mass deaths of the population in large regions or a significant deterioration in the population's quality of life. Allocate absolute and relative hunger.

According to the UN World Food and Agriculture Organization, one in seven people in the world suffers from chronic hunger and malnutrition. 1/4 of the Brazilian population, 1/3 of Nigeria, $1 / 3$ of the Indian population consume goods and services on less than one dollar a day. About 800 million people suffer from malnutrition in the world today. The World Health Organization estimates that ten are undernourished out of every 100 people currently living on the globe; 200 million people are on the brink of starvation (Ilyina et al., 2016). According to World Food and Agriculture Organization, the most affected by hunger and malnutrition (642 million) live in the Asia-Pacific region. It is followed by southern Africa, where there are 265 million such people (Durokifa \& Ijeoma, 2018). World Food and Agriculture Organization estimates that every third child in the world dies from hunger, and another 200 million children under the age of five go hungry regularly. Africa and Asia are leading in the list of child deaths from hunger. It is home to $90 \%$ of all starving children in the world, and 132 of a thousand children do not live to be five years old (Durokifa \& Ijeoma, 2018). In Russia, for example, this indicator is much lower - there are 13 deaths per thousand infants (Nazarenko, 2011).

In general, the question arises - is it possible to talk about some kind of progress in the development of mankind when most of the world's inhabitants find themselves not just below the poverty line but actually on the brink of survival. The gap between the quality of life in developed countries and developing countries is constantly growing. Although thanks to the newly developed countries and the money that the Arab countries receive from oil, this gap has recently been narrowing. If we talk about global trends, then gradually, the percentage of people suffering from malnutrition is decreasing.

\section{The problem of food scarcity in the world: current state}

Now economists are talking about the existence of a belt of hunger and malnutrition on Earth, stretching on both sides of the equator. This belt begins in South America, covers most of Africa, and then continues into Asia. This belt fits well with the belt of high fertility. The epicenter of this belt has long been located in Tropical Africa, the poorest region in the world. In the early 1970s. in Africa, there were 90 million hungry in the early 1980s. - 110 million in the mid-1980s. - 140 million in the mid-90s. - 210 million, at the beginning of the XXI century - 
170 million. There are countries in this region where the share of hungry and malnourished people in the entire population exceeds 40\% (Chad, Somalia, Uganda, Mozambique) or ranges from $30 \%$ to $40 \%$ (Ethiopia, Mali, Democratic Republic of the Congo, Zambia) (Lederer, 2020).

Despite the achievements of the Green Revolution, a rather difficult food situation persists in South-West, South, and SouthEast Asia. In South and Southeast Asia, the total number of hungry in 2018 was 290 million (Lederer, 2020). In Nepal, 70\% of the total population was undernourished, in India - more than $60 \%$, in Pakistan and Indonesia - 40\% (Lederer, 2020). Against the background of these figures, the problem of food supply in Latin America appears to be less acute. However, on this continent, too, the area of malnutrition covers many Andean countries. In them, the number of undernourished people reaches 60 million, and their share in the total population of some countries may be $40-45 \%$ (Efremov \& Vladimirova, 2019).

A report from the International Food Policy Research Institute, published in October 2018, found that of 122 developing countries, 25 countries are hungry. In total, one billion people are experiencing hunger in the world (Webb et al., 2018).

Let's turn to such an indicator as to the hunger index. The International Food Policy Research Institute developed the Global Hunger Index (GHI).

The hunger index is calculated based on three indicators:

1) the proportion of the undernourished population, as a percentage of the country's population;

2) for children under five years of age, lagging behind; mortality of children under five years of age.

The hunger index ranges from 0 to 100 points, where 0 points are the best result (no hunger), and 100 points are the worst indicator, although none of these extremes is achieved in practice. The index value is distributed as follows:

- 0 - 9.9 points - low level of hunger;

- 10.0 - 19.9 points - moderate hunger;

- 20.0 - 34.9 points - severe hunger;

- 35.0 - 49.9 points - a high level of hunger;

- 50 points and above - a very high level of hunger.

The value of the index of 20 points is already an alarming indicator. The Global Hunger Index currently assesses the situation in 122 developing countries and countries with economies in transition.

The average score for the world hunger index in 2019 was 27 points. The hunger index for some groups of countries is shown in Table 1.

The famine situation from 2000 to 2019 developed as follows. Performance deteriorated in nine countries: the DPRK and eight sub-Saharan African countries. The Democratic Republic of the Congo has the worst performance, with its hunger index rising $65 \%$ over the past ten years. Since 2010, there have been no changes or negative changes in 16 countries.

\section{Ways to solve global food security problems}

The organization responsible for the fight against hunger and malnutrition and the planet's food security is the United Nations Food Agriculture Organization (UN FAO). FAO was founded in 1945. FAO is currently the most representative and influential among 60 international organizations dealing with agriculture and food. FAO has developed a concept for international food security, created a system of international food order.

The term "food security" was first used at the international level in the 1970s in connection with the grain market crisis of 1972-73 (Abdullah, 2019; Osabohien et al., 2020). At the same time, the food problem was designated as a global problem. In connection with the crisis of 1974, the UN General Assembly adopted a special resolution, "international obligations to ensure food security in the world" (United Nations General Assembly, 2021). In this resolution, food security was defined as follows: "Food security is the provision of guaranteed access for all residents and at any time to the food resources of the world in the amount necessary for an active, healthy life" (United Nations General Assembly, 2021). In this definition attention is drawn to its social orientation. A social accentuation of this phenomenon characterizes almost all international documents addressing the food problem.

In 1995 the World Trade Organization (WTO) was established. All WTO member countries must commit themselves to domestic support for agriculture to reduce the volume of export subsidies according to the list of goods determined by the WTO.

Since then, the food problem has constantly been the focus of attention of world organizations. On November 13, 1996, at the World Summit in Rome, the "Plan of Action for the World Food Summit" was adopted. The World Summit

Table 1. Hunger index for some groups of countries.

\begin{tabular}{lccll}
\hline \multirow{2}{*}{ Hunger level } & \multicolumn{2}{c}{ number of countries } & & \multicolumn{2}{c}{ Examples of countries with hunger index } \\
\cline { 2 - 3 } & quantity & в $\%$ & \\
\hline moderate hunger & 43 & $45 \%$ & Albania (10.5), China (11.6), Dominican Republic (14.0), Indonesia (16.0), Mongolia (18.9) \\
severe hunger & 44 & $46 \%$ & Myanmar (20.1), Cambodia (23.7), Botswana (25.9), Angola (29.5), Sudan (34.8) \\
high hunger & 7 & $8 \%$ & Haiti (35.4), Sierra Leone (35.7), Zambia (37.6), Madagascar (38.0), Yemen (39.7), Chad (45.4) \\
very high hunger & 1 & 1.0 & CAR (53.7) \\
\hline
\end{tabular}

Compiled by the authors. 
Declaration emphasized the recognition of "the need for policies that promote investment in human resources development, research, and infrastructure to achieve food security." (Food and Agriculture Organization of the United Nations, 1996). The Rome Declaration determined: "we will ensure an enabling political, social, and economic environment designed to create the best conditions for the eradication of poverty and for durable peace, based on full and equal participation of women and men, which is most conducive to achieving sustainable food security for all" (Food and Agriculture Organization of the United Nations, 1996). As already emphasized above, once again an international document, in this case, the "Rome Declaration," focused on the social aspects of the food problem. As a result of this meeting, one of the international goals was announced to reduce the percentage of hungry and chronically malnourished people worldwide by 2017. In order to achieve a halving of the share of the hungry population by 2017 , it had to be reduced by 20 million annually while since the beginning of the 1990s. The annual decline in this indicator was less than 8 million. As a result, by 2017, this problem had not been resolved.

In 2001, the UN General Assembly read the report "The Human Right to Food," prepared at the Commission on Human Rights initiative. This document formulated the rights of all people to food, including during military and other conflicts, and specific measures to solve the food problem.

Currently, various UN structures - the UN Food and Agriculture Organization (FAO), the UN World Food Program (UNFPA), the International Fund for Agricultural Development (IFAD), and others have proposed a series of programs to solve the food problem. For 60 years, within the framework of the UN FAO, the World Food Program has been operating, according to which food aid has been provided to 120 of the poorest countries in the world. The International Food Reserve has been created on the planet. FAO has a Committee on World Food Security, which is responsible for the implementation of the Plan of Action adopted by the Rome World Food Conference.

The importance of the food problem is one way or another touched upon in forty international human rights documents adopted since 1924. The main ones are: "Declaration of the Rights of the Child ("Geneva Declaration") (1924), "Universal Declaration of Human Rights" (1948), "Declaration of the Rights of the Child" (1959), "International Covenant on Economic, Social and Cultural Rights" (1996), "Declaration on the Right to Development" (1986), "Convention on the Rights of the Child" (1989), "World Declaration on the Survival, Protection and Development of Children" and "Action plan for its implementation" (1990), etc. Problems of environmental safety of products are addressed in a number of documents of the World Trade Organization.

As for specific mechanisms for solving the problem, industrialization, post-industrialization, liberalization of economic life, transformation and modernization of agrarian relations, reform of education and health care, mitigation of inequality, implementation of a rational demographic policy, and solution of employment problems are proposed as such. At the same time, this position does not deny assistance to developing countries from outside. But this should just help, not "feeding." Currently, this assistance is carried out primarily through the so-called official development assistance from developed countries in the form of financial resources. For the poorest countries (namely, they are the main recipients of this aid), official development assistance is more than 3\% in relation to their GDP, including for the countries of Tropical Africa - even more than 5\%, although for each inhabitant of this region this is only $\$ 26$ per year (Tambovceva et al., 2020).

Another way of assistance is foreign and private investment - direct and portfolio, as well as bank loans. According to the IMF, in 2010, the net inflow of all financial resources that went to developing countries ranged from \$ 114 to \$ 229 billion annually.

Tackling hidden hunger is an important part of the solution to the food problem. Latent hunger is a lack of vitamins, microelements, proteins in the diet, the low-calorie content of food. Almost every country in the world has been fighting hidden hunger for the past 20 years. For this, measures such as the mandatory enrichment of mass products with vitamins, folic acid, trace elements, iodine, etc., are carried out. Industrial enrichment of food products or their biofortification is carried out (for example, the cultivation of sweet potatoes). Food additives are used.

For example, in Venezuela in 2014-2015. the incidence of anemia in children 7-15 years old decreased from $37 \%$ to $19 \%$ due to food fortification with iron. Similar activities carried out in Peru have reduced the number of anemic children by almost five times in six months. Prevention of micronutrient deficiency in the United States prevents four out of ten child deaths, reduces maternal mortality by a third, and increases efficiency by $40 \%$. Measures are being introduced to encourage the production of a wide range of nutrient-rich plants.

\section{Results of solving the problem: achievements and failures}

With a massive famine, when more than one million people die in a certain region, mankind has not faced it for several decades. Overall, the fight against hunger is undoubtedly bearing some fruit. From 2000 to 2018, hunger rates in developing countries fell by $29 \%$. But this process is uneven at the regional, national, and subnational levels. If we exclude China from the statistics, the decline will be $29 \%$, but only $19 \%$.

Despite the efforts made, it was not possible to achieve the goals set in 1996 at the World Summit in Rome and in 2000 in New York at the UN session. As mentioned above, the 1996 World Summit in Rome set a goal to reduce the number of hungry and chronically malnourished people for widows by 2017. The Millennium Declaration adopted by the UN in 2000 set the same goal by 2015 (to reduce the percentage of hungry people from $20 \%$ to $10 \%$ ). Both goals were not achieved. In order to achieve a halving of the share of the hungry population by 2017 , it had to be reduced by 20 million annually while since the beginning of the 1990s. The annual decline in this indicator was less than 8 million. As a result, neither 2015 nor 2017 has this problem been solved. In September 2010, a UN summit was 
held to summarize the preliminary results of the Millennium Development Goals. It was noted that the situation had improved over ten years. The number of people living below the poverty line has decreased from 1.8 billion in 1990 to 1.4 billion in 2005 . But there was no twofold reduction.

Obviously, only those countries that are actively reforming and modernizing their agriculture have achieved success in the fight against hunger and poverty so far. In this area, the following changes have occurred over the past 20 years.

According to the World Bank, from 1980 to 2018, the gross world agricultural product in the world increased by an average of $2 \%$, which outstripped the population growth rate of $1.6 \%$ per year. During this period, the rate of development of agriculture in developing countries amounted to $2.6 \%$ per year, in industrialized countries - $0.9 \%$. It should be noted that developing countries currently account for $79 \%$ of total world agricultural growth. Their share in total global agricultural GDP increased from $56 \%$ in 1980 to $65 \%$ in 2018 . Asia transition economies account for two-thirds of agricultural growth in developing countries.

The primary factor here is an increase in productivity and yield. Since the 1960s, irrigation, the introduction of improved varieties, and the use of fertilizers have contributed to the increase in cereal yields. The most active modernization of agricultural production took place in the countries of South and East Asia and the Pacific region. In sub-Saharan Africa, modernization is proceeding very slowly.

Livestock currently accounts for a third of the agricultural GDP of developing countries. Over the past 15 years, global meat production has doubled. The greatest dynamics were shown by the production and consumption of poultry meat, eggs, and fish. The emphasis on the development of "fast" meat is partly due to the well-known proportion: to get $1 \mathrm{~kg}$ poultry meat requires $2-3 \mathrm{~kg}$ feed, and $1 \mathrm{~kg}$ beef - three times more.

Aquaculture is particularly dynamic in its development. Its average annual growth rate from the beginning of the century to 2018 was $10 \%$. Over $90 \%$ of aquaculture production takes place in developing countries. China accounts for $67 \%$ of world production.

The next group of measures to address the food problem includes improving education and empowering women, creating adequate sanitation and hygiene, and ensuring public access to clean drinking water and health services.

It is not enough to support people only in emergencies and stop helping as soon as the crisis is over. Efforts must be made for continued support and long-term development. We need not only tactical but also strategic decisions.

FAO experts propose to rely on the following basic recommendations for solving the food problem on a global scale:

1. The right of people to nutritious and healthy food should be at the heart of the policy of solving the food problem;
2. Bridging the institutional, financial, and conceptual boundaries between humanitarian and development assistance;

3. Creation of long-term, flexible programs to solve the food problem will allow for multi-sectoral approaches to overcoming chronic food crises;

4. Continuous monitoring of such programs;

5. Active involvement of local people in programs to combat hunger and malnutrition;

6. Improving nutrition, especially for mothers and children.

Depending on the value of the hunger index, FAO experts suggest three basic strategies to combat the food problem:

\section{Takeover strategy.}

Resources and assistance are used to reduce the impact of the crisis without changing people's lifestyles (for example, they will not have to sell livestock)

\section{Adaptation strategy.}

After solving the actual problem, measures are proposed to improve the situation (for example, the introduction of droughtresistant varieties).

\section{Strategy of transformation.}

If adaptation strategies are insufficient to cope with the negative impact of the food crisis, fundamental, longer-lasting changes are proposed (for example, nomadic tribes become sedentary).

Apparently, global action is also needed, including the revision of the economic development models of the world's poorest countries. It should be noted that the model of these countries turned out to be unsuccessful and should be revised.

Oxfam International provides the following recommendations for solving the food problem:

1. - at the global level, develop programs for developing countries to increase their own public investment in key sectors of the economy, especially in agriculture;

2. - to support the reformed World Food Security Committee as the main forum for the development and coordination of global actions to address the problems of global food security governance, to identify the root causes of hunger and malnutrition;

3. - Increase by $\$ 75$ billion annually in investments in agriculture and rural development, food security, social protection, and food assistance programs;

4. - recognize and strengthen the fundamental role of women in ensuring food security;

5. - regulate food markets to reduce speculation and price volatility. 


\section{Conclusion}

Global problems of the world economy are problems that concern all countries of the world and require resolution by combining the efforts of all members of the world community. Various authors identify from seven to 20 global economic problems of our time.

The food problem is complex and closely related to environmental problems, raw materials problems, problems of inequality, poverty, and poverty political and social problems. The world food problem is called one of the main unresolved problems of the XX-XXI centuries. Over the past 50 years, significant progress has been made in food production - the number of undernourished and hungry people in the world has decreased by a third. At the same time, a huge part of the world's population still suffers from food shortages. The number of those in need exceeds one billion people. About 18 million people die of hunger every year, especially in developing countries.

The problem of food shortages is most acute in developing countries. Economists talk about the existence of a belt of hunger and malnutrition on Earth, stretching on both sides of the equator. This belt begins in South America, covers most of Africa, and then continues into Asia. This belt fits well with the belt of high fertility. The average hunger index in the world in 2018 was 27 points. At the moment, the maximum hunger level of 50-60 points is typical for the countries of Central Africa. Despite the efforts made, it was not possible to halve the level of hunger by 2016, as planned.

So far, only those countries actively reforming and modernizing their agriculture have succeeded in the fight against hunger and poverty.

Depending on the value of the hunger index, three basic strategies are proposed to combat the food problem:

\section{1. Takeover strategy.}

7.2. Adaptation strategy.

8.3. Strategy of transformation.

\section{References}

Abdullah, A. (2019). Identifying agriculture land acquisitions for alleviating future food security concerns. Food Science and Technology (Campinas), 39(2), 301-307. http://dx.doi.org/10.1590/fst.24917.

Baer, T. E., Scherer, E. A., Fleegler, E. W., \& Hassan, A. (2015). Food insecurity and the burden of health-related social problems in an urban youth population. The Journal of Adolescent Health, 57(6), 601-607. http://dx.doi.org/10.1016/j.jadohealth.2015.08.013. PMid:26592328.

Balakina, G. F. (2015). Specifics of forming a regional socioeconomic development strategy in the context of modernization. Regional Research of Russia, 5(3), 270-275. http://dx.doi.org/10.1134/ S2079970515030028.

DeBacker, J., Heim, B. T., \& Tran, A. (2015). Importing corruption culture from overseas: evidence from corporate tax evasion in the United States. Journal of Financial Economics, 117(1), 122-138. http://dx.doi.org/10.1016/j.jfineco.2012.11.009.
Durokifa, A. A., \& Ijeoma, E. C. (2018). Neo-colonialism and Millennium Development Goals (MDGs) in Africa: a blend of an old wine in a new bottle. African Journal of Science, Technology, Innovation and Development, 10(3), 355-366. http://dx.doi.org/10.1080/20421338 .2018.1463654.

Efremov, V. S., \& Vladimirova, I. G. (2019). Globalization of the world economy: features of the current stage. Economic and Social Development: Book of Proceedings, 27-36.

Food and Agriculture Organization of the United Nations. (1996). Report of the World Food Summit. Retrieved from: https://www. fao.org/3/w3548e/w3548e00.htm.

Food and Agriculture Organization of the United Nations. (1996). Rome declaration on World Food Security. Retrieved from: https:// www.fao.org/3/w3613e/w3613e00.htm.

Goncharova, N. A., Kondratenko, I. S., \& Zamaraeva, E. N. (2018). Economic mechanism of industrial enterprise resources management efficiency assessment. The Journal of Social Sciences Research, 4(12), 470-477.

Goncharova, N. A., Solosichenko, T. Z., \& Merzlyakova, N. V. (2019). Brand platform as an element of a company marketing strategy. International Journal of Supply Chain Management, 8(4), 815.

Ilyina, Z. M., Ganush, G. I., Mirochitskaya, I. V., Bajgot, L. N., Belskij, V. I., Bondarchuk, V. F., Krylovich, T. A., Meleshchenya, A. V., Korotina, A. N., \& Bajgot, M. S. (2004). Agricultural products and raw materials markets. Minsk: BSEU, 2016.

Izakova, N. B., \& Kapustina, L. M. (2018). Measuring relationship marketing productivity in the industrial market. Upravlenec, 9(5). http://dx.doi.org/10.29141/2218-5003-2018-9-5-8.

Kapoguzov, E. A. (2019). Double helix of institutional import in public administration reform in Russia. Upravlenets, 10(5), 33-40. http:// dx.doi.org/10.29141/2218-5003-2019-10-5-4.

Karkh, D. A., \& Morozova, M. P. (2018). Efficiency of interregional relations of logistics distribution centres. Upravlenets, 9(1), 56-64. http://dx.doi.org/10.29141/2218-5003-2018-9-1-8.

Kemsley, E. K., Defernez, M., \& Marini, F. (2019). Multivariate statistics: Considerations and confidences in food authenticity problems. Food Control, 105, 102-112. http://dx.doi.org/10.1016/j. foodcont.2019.05.021.

Konnikov, E. A., Konnikova, O. A., Dubolazova, Y. A., \& Mansurov, R. D. (2020). Dialectics of the Renewable energy market. In Proceedings of the European Conference on Innovation and Entrepreneurship. SRJ.

Lederer, N. (2020). Extending your reach: creating topical guides featuring government information. DttP, 48(2), 7-11. http://dx.doi. org/10.5860/dttp.v48i2.7357.

Merzlyakova, N. V., \& Goncharova, N. A. (2020). Investigation of import substitution and expansion impact in Russian foreign economic practice by supply chain strategy. International Journal of Supply Chain Management, 9(2), 772.

Nazarenko, V. I. (2011). Food security in the world and in Russia (286 p.). Moscow: Monuments of Historical Thought.

Osabohien, R., Ufua, D., Moses, C. L., \& Osabuohien, E. (2020). Accountability in agricultural governance and food security in Nigeria. Brazilian Journal of Food Technology, 23, e2019089. https:// doi.org/10.1590/1981-6723.08919.

Pisani, N., Kourula, A., Kolk, A., \& Meijer, R. (2017). How global is international CSR research? Insights and recommendations from a systematic review. Journal of World Business, 52(5), 591-614. http:// dx.doi.org/10.1016/j.jwb.2017.05.003. 
Ssennoga, F., Mugurusi, G., \& Oluka, P. N. (2019). Food insecurity as a supply chain problem. Evidence and lessons from the production and supply of bananas in Uganda. Scientific American, 3, e00076.

Swaffield, J., Evans, D., \& Welch, D. (2018). Profit, reputation and 'doing the right thing': Convention theory and the problem of food waste in the UK retail sector. Geoforum, 89, 43-51. http://dx.doi. org/10.1016/j.geoforum.2018.01.002.

Tambovceva, T., Ivanov, I. H., Lyulyov, O., Pimonenko, T., Stoyanets, N., \& Yanishevska, K. (2020). Food security and green economy: Impact of institutional drivers. International Journal of Global Environmental Issues, 19(1-3), 158-176. http://dx.doi.org/10.1504/ IJGENVI.2020.114871.

United Nations General Assembly. (2021). United Nations General Assembly. Retrieved from: https://en.wikipedia.org/wiki/United_ Nations_General_Assembly.

Webb, P., Stordalen, G. A., Singh, S., Wijesinha-Bettoni, R., Shetty, P., \& Lartey, A. (2018). Hunger and malnutrition in the 21st century.
BMJ (Clinical Research Ed.), 361, K361. http://dx.doi.org/10.1136/ bmj.k2238. PMid:29898884.

Yousefi, K., Vesal, M., \& Pilvar, H. (2020). Import tax evasion and avoidance: evidence from Iran. The Quarterly Review of Economics and Finance, 75, 31-39. http://dx.doi.org/10.1016/j. qref.2019.05.010.

Zavorohina, N. V., Pankratieva, N. A., \& Goncharova, N. A. (2019). Improving preservation methods consumer characteristics of bread long-term storage. In Proceedings of the International Scientific Conference, Fifth Technological Order: Prospects for the Development and Modernization of the Russian Agro-Industrial Complex. The Netherlands: Atlantis Press.

Zavorokhina, N. V., Pankratieva, N. A., \& Goncharova, N. A. (2019). New technologies for the production of wheat bread long-term storage under the conditions of new industrialization. Advances in Social Science Education and Humanities Research, 240, 62-65. 